\title{
Study Comparative of Products Biogas Using Difference Raw Material from Animal Dung
}

\author{
1Surjono Adi Walujo, 2Nurfa Anisa, 3Aris Budi Harsanto
}

1Lecturer, Merdeka University Madiun.

2Lecturer, Merdeka University Madiun.

${ }_{3}$ Lecturer, Merdeka University Madiun.

Correspondence Author: Surjono Adi Walujo, Lecturer, Merdeka University Madiun,

E-mail: suryono2007@yahoo.co.id

Received date: 22 December 2017, Accepted date: 22 January 2018, Online date: 5 February 2018

Copyright: ( $) 2018$ Surjono Adi Walujo. This is an open-access article distributed under the terms of the Creative Commons Attribution License, which permits unrestricted use, distribution, and reproduction in any medium, provided the original author and source are credited.

\begin{abstract}
The energy crisis that occurred recently made the whole world began to direct attention to alternative energy sources as a substitute for fossil fuels. One source of renewable energy potential is biogas. Biogas itself can be derived from the remains of plants, animal waste, human waste, industrial waste, and all elements that can produce metan gas. This research aims to test the superiority of quail dung as a raw material biogas compared to other raw materials are: chicken dung and cow dung.
\end{abstract}

Key words: biogas, methan gas, quail

\section{INTRODUCTION}

The energy crisis that occurred recently made the whole world began to direct attention to alternative energy sources as a substitute for fossil fuels. To get a solution to possible shortage of fossil fuels and the environmental problems facing the world today acts long-term potential for sustainable development. In this case, a renewable energy source seems to be one of the most efficient solutions and effective.

One source of renewable energy potential is biogas. Biogas itself can be derived from the remains of plants, animal waste, human waste, industrial waste, and all elements that can produce methane gas. So that the main problems in this research is how to test and determine the raw materials which are the most superior of the three types of raw materials selected for use as raw material for biogas.

Literature:

A. Biogas:

Biogas globally have become known as a renewable energy source derived from plants that use solar energy during photosynthesis. Become a source of renewable natural gas, has been adopted as one of the best alternatives to fossil fuels as the world energy crisis in the 1970s. Physically biogas is a colorless, flammable gas is produced through anaerobic digesting from animal manure, plant litter, human waste, industrial waste and municipal sewage, to produce mainly of methane (50-70\%), carbon dioxide (20-40\%) and follow-up of other gases such as nitrogen, hydrogen, ammonia, hydrogen sulfide, water vapor and others. This biogas burns without smoke, hygienic and more comfortable to use than any other solid fuel. The average temperature in Indonesia ranges from $20 \mathrm{oC}$ to $30 \mathrm{oC}$. This is the ideal temperature for fermentation of organic material. So biogas is an alternative energy source that is prospective in Indonesia.

\section{B. Process Biogas:}

Anaerobic digestion has been regarded as waste-to-energy technologies, and is widely used in the processing of organic waste that is different, for example: the organic fraction of municipal solid waste, sewage sludge, food waste, animal waste, and others.

Processing is the process of anaerobic decomposition of organic material in the absence of free oxygen and produces methane, carbon dioxide, ammonia and other gases followup and mild organic acid molecule. Overall reaction to changes in the organic matter into methane gas and carbon dioxide can be written as the following equation:

$(\mathrm{C} 6 \mathrm{H} 10 \mathrm{O} 5) \mathrm{n}+\mathrm{n} \mathrm{H} 2 \mathrm{O} \rightarrow 3 \mathrm{n} \mathrm{CO} 2+3 \mathrm{n} \mathrm{CH} 4$

The above equation becomes valid when the substrate is cellulose. For the substrate in the form of complex organic compounds, such as lignin and tannin and other aromatic polymer compounds, methane formation is not through a reaction like the one above. The substrate in the form of aromatic compounds simpler through aerobic activity several extracellular enzymes produced by a microorganism. Simple aromatic compounds is generally benzenoid. Furthermore, this benzenoid compounds through metaorganik bacterial activity, such as Methano-bacterium formicum and Methanospirilum hungati, anaerobically converted to methane and carbon dioxide. This process of change occurs through the reaction stages as follows:

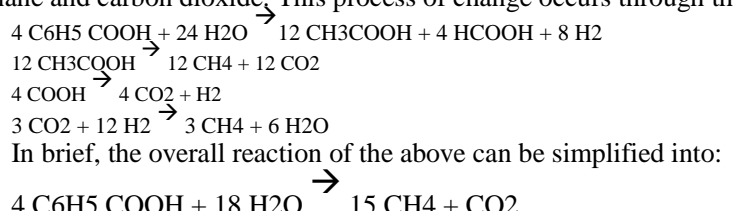


Raw materials for biogas fermentation such as cow dung, poultry droppings, water hyacinth, straw, weeds, leaves, human and animal waste, domestic waste and industrial solid and liquid wastes are easily available in Indonesia.

Biogas digester is the apparatus in which the process of digesting happen. Organic raw materials incorporated into the digester and allowed to undergo degradation in a sealed oxygen-free space. Figure 1. show digester used this research. This digester vessel made of plastic. The main parts are: hopper where the mixture of mud shaped material (slurry) is inserted in the digester through this hopper, inlet pipes that drain the mud from the hopper to the digester, digester or fermentation room, where the fermentation process occurs. The digester has two parts: one is the top that is used for storage of biogas is referred to as a gas tank, and the bottom is joined with the top of the bolt connection for easy handling of sludge. There is a gas pipeline to transport the gas from fermentation. The gas stream is controlled by a gas valve.

Fig. 1: Biogas digester

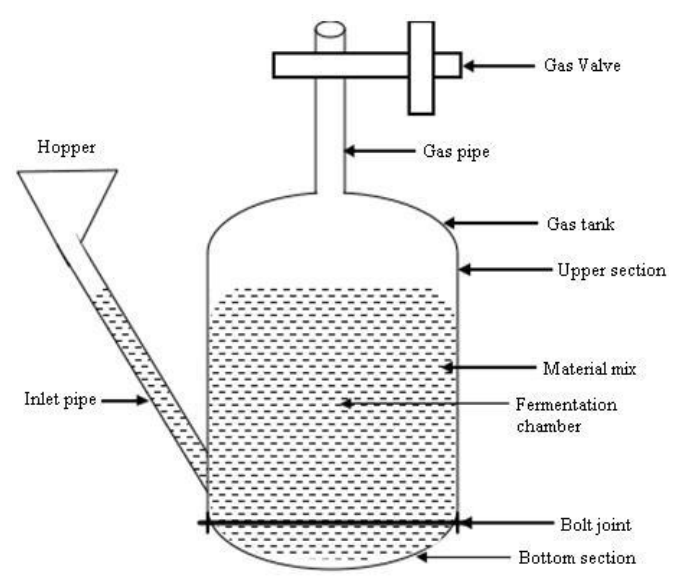

C. Manure Biogas As Raw Material:

In general, almost all manure can be used as raw material for biogas. But there are some things that must be considered such as: the composition of the dirt itself and certainly is the availability of raw materials is continuously in the long term.

Utilization of manure as an energy source, does not reduce the amount of organic fertilizer derived from manure. This is because the biogas processing, manure processed restored to its original state as taken only methane gas is used as fuel.

Judging from the aspect of availability, as the main component of manure producing biogas available in farming households where livestock cattle manure produced each day. In addition, livestock manure is easily accessible by farming households that meet accessability aspect. Judging from the aspect of acceptability, public acceptance of biogas still needs to be built. Acceptability aspect is very important for the development of biogas must be preceded by public acceptance in this case of farming households to biogas. There are some people who feel disgusted with livestock manure as a raw material for biogas and uncomfortable to dishes cooked using biogas. There are also some people who just want to take advantage of instant energy that is immediately available thus less interested in the development of biogas does require patience in the process of formation of biogas, from the introduction of manure into the digester, gas pressure control, to processing residues out of the digester. If the attitude of society has been built to be willing to take advantage of local potentials that exist around them, the biogas can be developed as an alternative energy that can be created independently and used sustainably.

Purpose and Benefit Research:

The specific objective of this study are:

- Compare products biogas from animal manure feedstock different, especially dung quail, chicken manure and cow dung.

- To examine the advantages of raw materials biogas from dung quail compared with the raw material of biogas from chicken manure and cow dung to Investigate the superiority of examine the chemical composition of biogas product of some sort of animal waste mainly methane gas content.

- $\quad$ Determine the biogas potential feedstock for biogas production process.

In the quail farm, manure produced is estimated to have ingredients that can produce biogas promising. This is because the food is consumed containing protein quail in high enough levels. In addition, by-product or waste from processing quail dung into biogas can be directly used as fertilizer without having to be processed again.

Methods:

A. Location Research:

Research conducted at two locations, namely: Laboratory of the Faculty of Engineering Unmer Madiun, Unmer Madiun Laboratory of the Faculty of Agriculture.

B. Equipment and Materials Research:

The materials used in this study are:

- $\quad$ Quail dung

- $\quad$ Chicken dung

- $\quad$ Cow dung

To obtain a mixture (slurry) needed enough water, it is estimated that about 5 to 12 percent of the total solids.

- $\quad$ A set of digester

- A set of measuring gas

- A set of pressure gauges equipment. All three devices are arranged and set into a unity so as to facilitate handling and record keeping. And to save time provided each of the 3 sets of

\section{Procedure Research:}

Schematically, research equipment be in figure 2 . 
Fig. 2: Schematic of research equipment

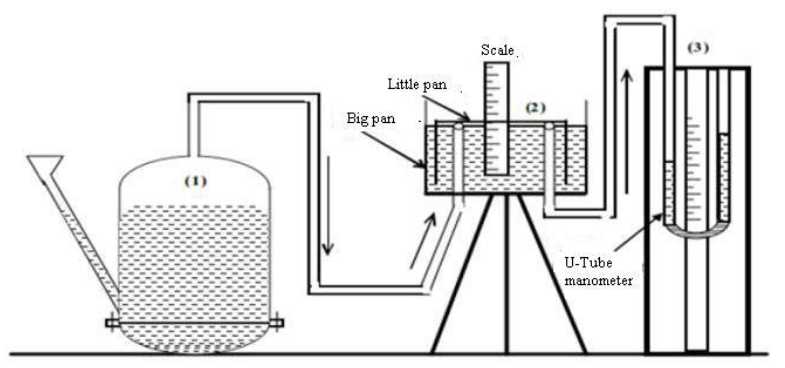

There are three main parts: the first part (1) is a digester with gas pipes and valves. Two (2) and three (3) sections that measure gas and part of the pressure gauge. Biogas is produced in the digester and fed to the measuring section through a gas pipe and valve. Gas is collected by water displacement method. This configuration consists of a larger pot made of sheet GP and a small pot made of plastic that is very light. Two pipes is inserted from the bottom of a large pot. One is from the digester and the other from the manometer. Small pot placed over these two pipes in a larger pot upside down. Water is poured into a large pan until the water reached the top of the pipe. When the water level touches the bottom of the pot is small, the air in a small saucepan flow through a pipeline connected manometer. The gas pressure was measured with a water manometer Tube-U. Before the gas is produced, the volume of gas storage and gas pipeline filled with air. When the gas produced in the digester, the gas pushes the air into a small saucepan gas meter, so that the gas gauge pan lifted. Initially the air is taken out of the pot and after some time the biogas collected and measured. The volume of gas measured by the formula $V=\square r^{2} h$ ( $r$ is the radius of the cylinder pot and $h$ is the height of the pot from the surface of the water).

The time required for data recording is about 25 days or more, or until the digester does not produce methane gas again. If methane is not formed again, the recording process is stopped. For each fermentation process is repeated up to three times, and then averaged.

\section{RESULT AND DISCUSSIONS}

The experimental results can be seen as in Figure 3 below.

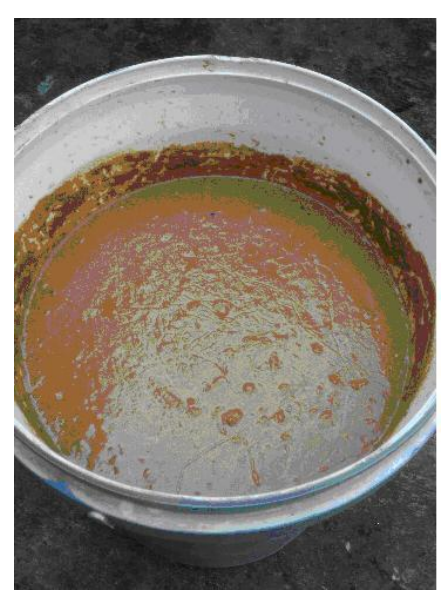

Fig. 3: Slurry preparation

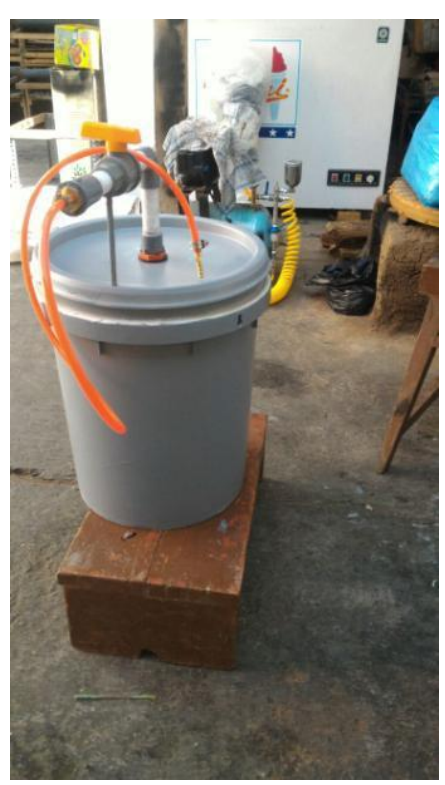

Fig. 4: Equipment of experiment 
Citation: Surjono Adi Walujo, Nurfa Anisa, Aris Budi Harsanto, 2018. Study Comparative of Products Biogas Using Difference Raw Material From Animal Dung. Advances in Natural and Applied Sciences., 12(1): 6-10.

Fig. 5: Obtaining biogas
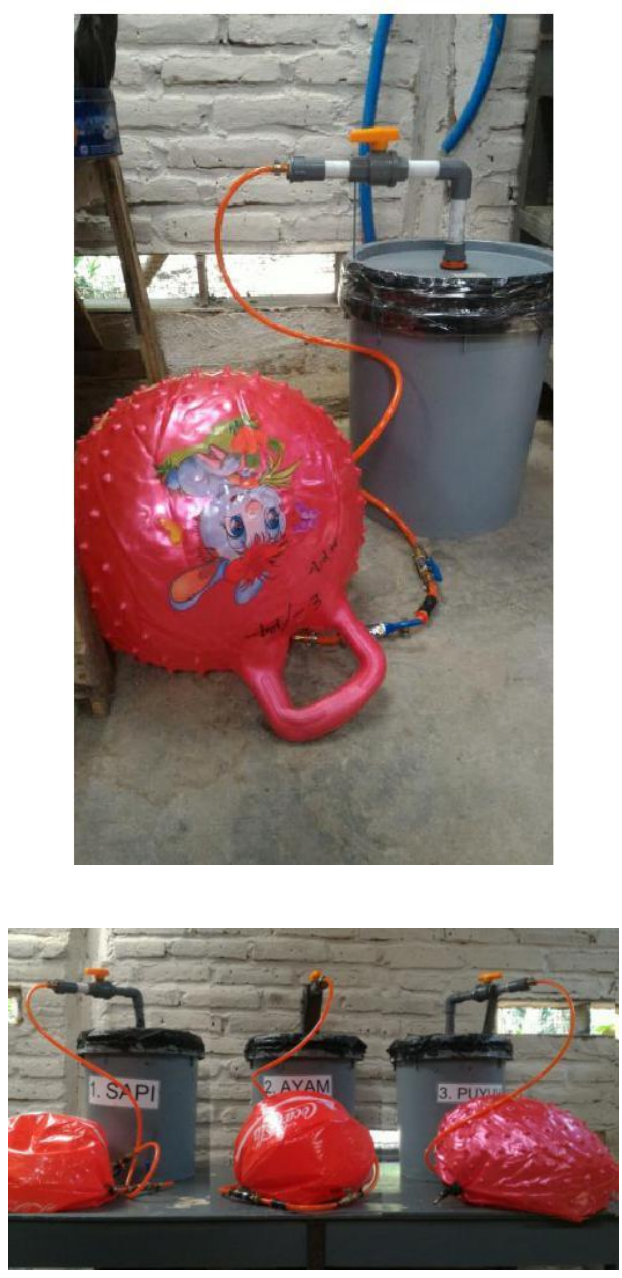

Fig. 6: Result of experiment

The data taken in the experiment consists of a number of gases that come out of the digester, the gas pressure, and others. Furthermore, the data are tabulated as follows.

Table 1: Data from experiments

\begin{tabular}{|c|c|c|c|}
\hline Day & Cow $\left(\mathrm{m}^{3}\right)$ & Chicken $\left(\mathrm{m}^{3}\right)$ & Quail $\left(\mathrm{m}^{3}\right)$ \\
\hline 1 & 0 & 0,0124 & 0,0093 \\
\hline 2 & 0 & 0,0153 & 0,0112 \\
\hline 3 & 0 & 0,0147 & 0,0114 \\
\hline 4 & 0 & 0,0187 & 0,0142 \\
\hline 5 & 0,0041 & 0,0169 & 0,0131 \\
\hline 6 & 0,0052 & 0,0239 & 0,0162 \\
\hline 7 & 0,0063 & 0,0257 & 0,0174 \\
\hline 8 & 0,0074 & 0,0266 & 0,0178 \\
\hline 9 & 0,0069 & 0,0246 & 0,0165 \\
\hline 10 & 0,0094 & 0,0255 & 0,0189 \\
\hline 11 & 0,0134 & 0,0228 & 0,0209 \\
\hline 12 & 0,0131 & 0,0237 & 0,0188 \\
\hline 13 & 0,0152 & 0,0178 & 0,0242 \\
\hline 14 & 0,0165 & 0,0193 & 0,0251 \\
\hline 15 & 0,0157 & 0,0181 & 0,0269 \\
\hline 16 & 0,0162 & 0,0185 & 0,0294 \\
\hline 17 & 0,0142 & 0,0189 & 0,0309 \\
\hline 18 & 0,0202 & 0,0161 & 0,0317 \\
\hline 19 & 0,0195 & 0,0157 & 0,0309 \\
\hline 20 & 1,0191 & 0,0151 & 0,0318 \\
\hline Day & Cow $\left(m^{\circ}\right)$ & Chicken $\left(\mathrm{m}^{3}\right)$ & Quail $\left(\mathrm{m}^{3}\right)$ \\
\hline 21 & 0,0282 & 0,0167 & 0,0329 \\
\hline 22 & 0,0243 & 0,0174 & 0,0312 \\
\hline 23 & 0,0261 & 0,0155 & 0,0271 \\
\hline 24 & 0,0269 & 0,0148 & 0,0302 \\
\hline 25 & 0,0245 & 0,0131 & 0,0251 \\
\hline 26 & 0,0262 & 0,0135 & 0,0243 \\
\hline 27 & 0,0241 & 0,0152 & 0,0203 \\
\hline 28 & 0,0224 & 0,0121 & 0,0193 \\
\hline 29 & 0,0187 & 0,0161 & 0,0205 \\
\hline
\end{tabular}


Citation: Surjono Adi Walujo, Nurfa Anisa, Aris Budi Harsanto, 2018. Study Comparative of Products Biogas Using Difference Raw Material From Animal Dung. Advances in Natural and Applied Sciences., 12(1): 6-10.

\begin{tabular}{|l|l|l|l|}
\hline 30 & 0,0196 & 0,0177 & 0,0184 \\
\hline 31 & 0,0143 & 0,0117 & 0,0198 \\
\hline 32 & 0,0193 & 0,0149 & 0,0191 \\
\hline 33 & 0,0197 & 0,0137 & 0,0195 \\
\hline 34 & 0,0052 & 0,0157 & 0,0184 \\
\hline 35 & 0,0047 & 0,0142 & 0,0213 \\
\hline 36 & 0,0036 & 0,0147 & 0,0191 \\
\hline 37 & 0,0032 & 0,0121 & 0,0182 \\
\hline 38 & 0,0042 & 0,0101 & 0,0163 \\
\hline 39 & 0,0024 & 0,0087 & 0,0141 \\
\hline 40 & 0,0019 & 0,0072 & \\
\hline
\end{tabular}

From the data in table 1. can be plot as figure 7. below.

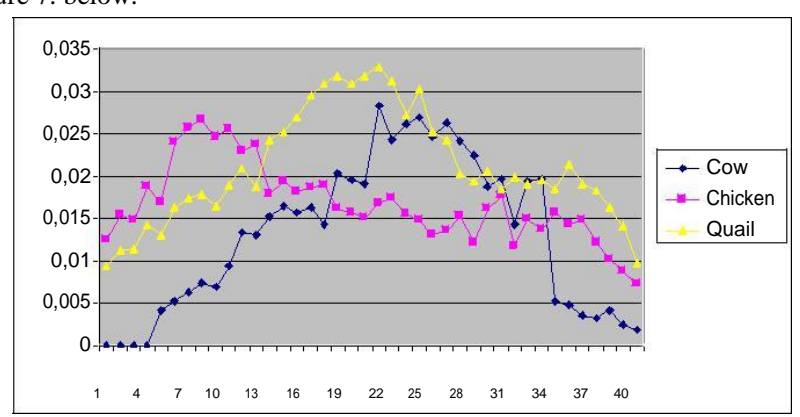

Fig. 7: Comparation between three of raw material

From the graph in figure 7. in biogas products with material from quail dung, maximum gas recovery occurred on day 15 to day 28 , ie between $0.25 \mathrm{~m}^{3}$ to $0.32 \mathrm{~m}^{3}$, meanwhile the maximum gas recovery occurred on day 21 is $0.329 \mathrm{~m}^{3}$.

It can be seen that biogas with raw materials from quail dung globally is superior compared to biogas products with raw materials from cow dung and chicken dung. Thus the quail droppings can be used as feedstock for biogas production, with adequate results.

Conclusion:

Utilization of quail dung as raw material for biogas has a pretty good prospect. By utilizing better technology will be produced biogas with quality and adequate quality, either for commercial purposes or for energy needs in the farm itself.

\section{ACKNOWLEDGEMENTS} Madiun.

The authors would like to thank the head of Laboratory of the Faculty of Engineering and Laboratory of the Faculty of Agriculture Merdeka University

This research project was fully funded by DP2M from The Ministry of Research, Technology and High Education with contract number: 012/SP2H/HBHB/Unmer,Mdn/ LPPM/IV/2016.

Lists of Symbols:

V The volume of gas

$r \quad$ the radius of the cylinder pot

h height of the pot from the surface of the

water $\mathrm{CH} 4$ methane

$\mathrm{CO} 2$ carbon dioxide

$\mathrm{H} 2$ hydrogen

$\mathrm{H} 2 \mathrm{O}$ water

\section{REFERENCES}

[1] Argo Normak, Andres Menind, 2010, Animal wastes and energy production: manure, biogas, compost, Seminar "Animal production" Tartu.

[2] Kaharudin, Farida Sukmawati M., 2010. PETUNJUK PRAKTIS MANAJEMEN UMUM LIMBAH TERNAK UNTUK KOMPOS DAN BIOGAS, Kementerian Pertanian, Badan Penelitian dan Pengembangan Pertanian, Balai Besar Pengkajian dan Pengembangan Teknologi, Balai Pengkajian Teknologi Pertanian NTB.

[3] Md. Forhad Ibne Al Imam, M.Z.H., M.A.R. Khan, S.M. Sarkar, Ali, 2013. Development of Biogas Processing from Cow dung, Poultry waste, and Water Hyacinth, International Journal of Natural and Applied Science.

[4] Md Saidul Borhan, Shafiqur Rahman, and Heekwon K. Ahn, 2012. Dry Anaerobic Digestion of Fresh Feedyard Manure: A Case Study in a Laboratory Setting, Int. J. Emerg. Sci., 2(4): 509-525.

[5] Roshani, A., J. Shayegan, A. Babaee, 2012. Methane Production from Anaerobic Co-Digestion of Poultry Manure, Journal of Environmental Studies, 38 : 62.

[6] Ukpai, P.A. and M.N. Nnabuchi, 2012. Comparative study of biogas roduction from cow dung, cow pea and cassava peeling using 45 litres biogas digester, Advances in Applied Science Research, 3(3): 1864-1869. 